\title{
ABORSI DALAM PERSPEKTIF HUKUM ISLAM (Suatu Analisis dengan Pendekatan Fiqh al-Muqârin)
}

\author{
Abd. Gani Jumat \\ STAIN Datokarama Palu, Jl. Diponegoro 23 Palu \\ e-mail: gani.jumat@gmail.com
}

\begin{abstract}
Abortion is one of the contemporary law problems frequently debated. In Indonesia, abortion is not only a law problem but also a moral problem. Posing abortion within the law and moral perspective bocomes important since it is related to the law dealing with the termination of a child's right to life. This article deals with the status of abortion within the Islamic law and moral perspective, employing the method of fiqh almuqârin (comparative figh), that is by comparing and conforming the ikhtilâf of abortion amongst the jurists (fuqahâ'). After analyzing the jurists' opinions of abortion, the writer found that since sperms and ovums come together and pertlization occurs, abortion is judged as a crime, and therefore the law status of which is proscribed.
\end{abstract}

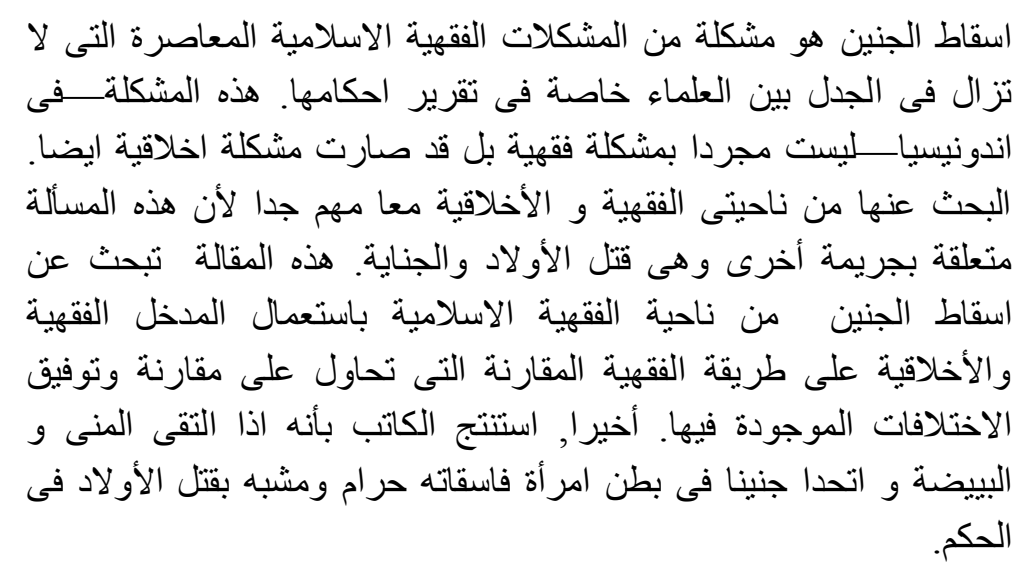

Kata Kunci: aborsi, hukum Islam, moral 


\section{PENDAHULUAN,}

Masalah aborsi telah menjadi salah satu patologi sosial masyarakat Indonesia yang serius pada masa kini. Aborsi merupakan isu yang kontroversial, khususnya bagi kalangan yang mengaitkannya dengan nilai-nilai moral dan norma-norma masyarakat. Demikian juga dengan respons undang-undang yang memandang aborsi sebagai suatu tindak pidana (Forum Kesehatan Perempuan, 2001). Hal ini disebabkan karena aborsi sering diasumsikan hanya pada kasus-kasus kehamilan di luar nikah.

Angka Kematian Ibu (AKI) pada setiap tahunnya boleh jadi disebabkan karena tidak adanya aturan mengenai pelayanan aborsi yang nyaman sehingga angka tersebut bukannya berkurang, tetapi justru semakin meningkat dan memberikan peluang yang besar terjadinya praktek aborsi secara diam-diam tanpa pedoman, prosedur, dan standar kesehatan. (LBH APIK, t.th.) Masalah ini tentu saja sangat memperihatinkan, padahal Pemerintah Indonesia telah menandatangani Kesepakatan Kairo 1994 chapter VII tentang hak-hak reproduksi dan kesehatan reproduksi yang salah satu programnya adalah mengeliminasi aborsi ilegal dan tidak aman. Oleh karena itu, dalam perspektif fikih, aborsi mendapat perhatian serius dari fuqaha, walaupun mereka memiliki persepsi dan preferensi yang berbedabeda.

Keragaman pandangan para fuqahâ' dalam melihat persoalan pengguguran kehamilan seakan-akan tenggelam oleh pandangan apriori masyarakat yang melihat aborsi dari perspektif agama sehingga seringkali agama terkesan memarginalkan hak-hak reproduksi perempuan. Ada lima persoalan pokok yang menjadi perdebatan di kalangan fuqahâ' sekitar masalah aborsi. Pertama, apa yang dimaksud aborsi; kedua, kapankah janin dianggap mulai hidup, apakah semenjak masa konsepsi (pembuahan dalam kandungan) atau ketika benih janin itu sudah berumur tertentu; ketiga, apakah semua jenis aborsi dilarang secara mutlak atau ada faktor-faktor pembenaran tertentu; keempat, apa akibat hukum, baik hukum agama maupun hukum positif terhadap pelaku aborsi; dan kelima, bagaimana upaya mencegah meluasnya aborsi di dalam masyarakat.

Kelima persoalan di atas menimbulkan perdebatan yang serius di kalangan fuqaha dan ahli-ahli agama lain. Agama-agama samawi (Yahudi, Kristen, dan Islam), di satu sisi memiliki kesamaan pandangan, tetapi di sisi lain juga memiliki perbedaan pandangan 
mengenai aborsi. Demikian pula, di antara para ahli dalam satu kelompok agama tertentu juga berbeda pendapat satu sama lain tentang masalah ini. Keprihatinan masyarakat terhadap aborsi dapat dibagi ke dalam dua kelompok, yaitu pertama, kelompok prokehidupan (pro-life) yang menyetujui dan mempertahankan pelestarian kehidupan dengan cara menentang aborsi, dan kedua ialah kelompok pro-pilihan (pro-choise) karena mendukung kebebasan reproduksi kaum perempuan dan menganggap aborsi adalah bagian dari hak asasi perempuan. Kedua kelompok ini saling memperebutkan pengaruh di dalam masyarakat. Kelompok pertama banyak didukung oleh kalangan agamawan, sedangkan kelompok kedua banyak didukung oleh kalangan liberal yang tidak mengindahkan pertimbangan-pertimbangan religiusitas.

Melihat problema aborsi di atas, penegasan kembali hukum aborsi penting dilakukan secara serius dan proporsional, baik berdasarkan fikih maupun hukum positif. Namun demikian, tentu saja perlu diiringi dengan pertimbangan akan hak-hak reproduksi perempuan sehingga pendekatan yang digunakan dalam membahas masalah aborsi, tidak cukup hanya dari perspektif moral dan hukum keagamaan, tetapi juga dari semua aspek termasuk aspek kepatutan kultural yang berkembang di dalam masyarakat.

Tulisan ini membahas persoalan aborsi dari perspektif agama dan fuqahâ', dengan tetap mempertimbangkan hak-hak reproduksi perempuan tanpa menafikan nilai-nilai moral, spiritual, dan kemaslahatan sosial yang menjadi tujuan agama.

TAHAP KEJADIAN MANUSIA, PENGERTIAN, CARA, DAN MACAM-MACAM ABORSI

\section{Tahap Kejadian Manusia}

Untuk mengetahui lebih jauh kapan dimulainya awal kehidupan janin, berikut ini dikemukakan beberapa ayat Alquran yang menjelaskan proses penciptaan manusia, yaitu:

Pertama, Q.S Al-Hâjj (22):5:

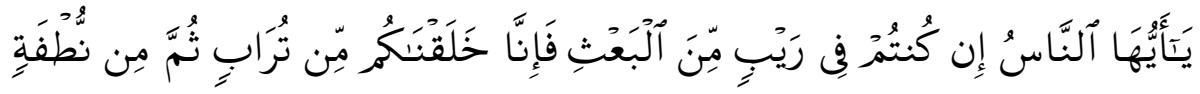

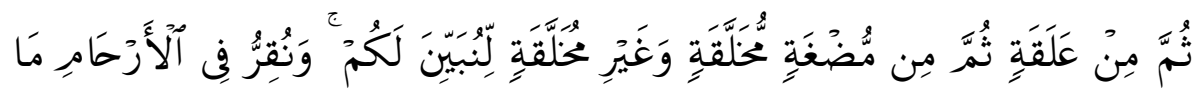




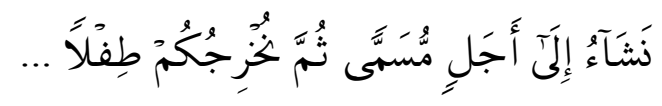

Terjemahnya:

Hai manusia jika kamu ragu tentang hari kebangkitan (dari kubur), maka (ketahuilah) sesungguhnya Kami telah menciptakan kamu dari tanah, kemudian dari setetes air mani, kemudian dari segumpal darah, kemudian dari segumpal daging yang sempurna kejadiannya dan yang tidak sempurna, afar Kami jelaskan kepadamu dan Kami tetapkan di rahimmu, apa yang kami kehendaki sampai waktu yang telah ditentukan, kemudian Kami keluarkan kamu sebagai bayi...

Kedua, Q.S Al-Mu'minûn (3):12-14:

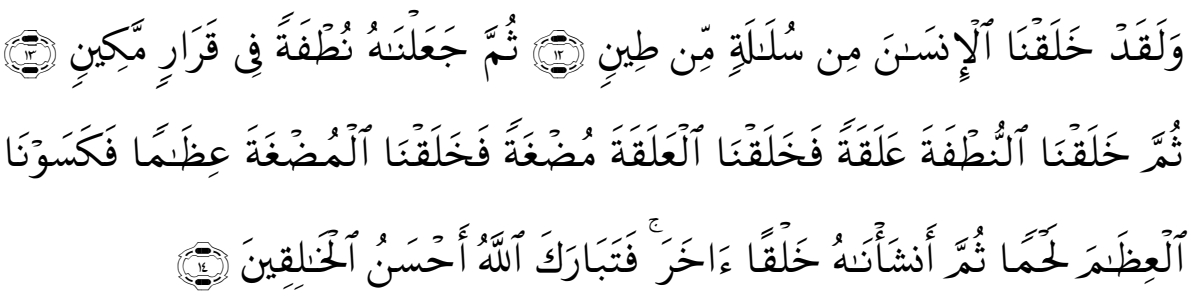

Terjemahnya:

Dan sesungguhnya Kami telah menciptakan manusia dari suatu saripati (berasal) dari tanah. Kemudian Kami jadikan saripati itu air mani (nuthfah) (yang disimpan) dalam tempat yang kokoh (rahim). Kemudian air mani itu Kami jadikan sesuatu yang melekat ('alaqah), kemudian sesuatu yang melekat itu Kami jadikan gumpalan daging (mudghah) dan gumpalan daging itu kami jadikan tulang-belulang ('izham), lalu tulang belulang itu Kami bungkus dengan daging, kemudian kami jadiakan dia mahluk yang berbentuk lain, maka maha sucilah Allah Maha Pencipta yang paling baik.

Menurut Sayyid Qutub (t.th.:14-15) ayat di atas memberikan penjelasan tentang reproduksi manusia melalui proses perkembangannya secara bertahap, yaitu mulai dari tanah sampai pada tahap sempurna menjadi manusia, tetapi bagaimana proses perkembangbiakan selanjutnya, Alquran tidak memberikan penjelasan yang lebih rinci. Hal ini memberikan kemungkinan ruang analisis dengan munculnya metode baru yang belum diketahui, tetapi yang jelas Alquran memuliakan manusia karena dalam diri manusia 
terdapat tiupan ruh Allah. Dari ayat di atas diketahui bahwa terdapat tahapan pertumbuhan dan perkembangan janin dalam rahim yang meliputi:

- Tahap sperma (nutfah)

Menurut Sayyid Qutub (t.th.:498) nutfahyang dimaksud di sini adalah setetes air mani atau sperma. Dalam Q.S Al-Qiyâmah (75):37, disebutkan:

Terjemahnya :

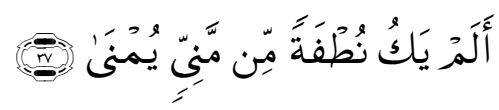

Bukankah dulu ia berasal dari setetes sperma yang ditumpahkan disebutkan:

Pada ayat yang lain dalam Q.S Al-Mu'minûn (23):12

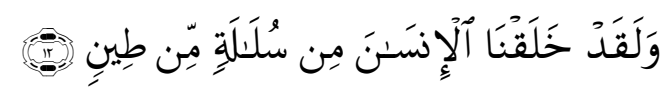

Terjemahnya:

Dan sesungguhnya Kami telah menciptakan manusia dari suatu saripati (berasal dari tanah)

- Tahap sesuatu yang melekat/gumpalan darah ('alaqah)

Kata 'alaqah oleh sebagian ulama dipahami sebagai "segumpal darah", berbeda dengan Sayyid Qutub yang memahami 'alaqah sebagai "sesuatu zat yang melekat" pada rahim ibu (Qutub, t.th.:16). Perubahan atau peralihan dari nutfahke 'alaqah terjadi ketika sperma laki-laki bercampur dengan ovum perempuan yang melekat pada dinding rahim, yang pada awalnya berbentuk zat yang kecil, yaitu nutfahyang memperoleh makanan dari darah ibu yang sedang mengandung. Kondisi melekat atau bergantungnya cikal-bakal organisme manusia ini, kemudian menjadi salah satu karakter dasar dirinya, sebagai makkhluk sosial yang selalu bergantung atau membutuhkan bantuan orang lain, sebagaimana ketergantungannya di dalam rahim ibunya.

- Tahap berbentuk gumpalan daging (lahm)

Seperti dijelaskan dalam Q.S Al-Mu'minûn (23) :14 :

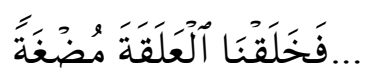


Terjemahnya:

...dari segumpal darah itu kami jadikan segumpal daging

Peralihan dari 'alaqah ke mudghah menurut Sayyid Qutub, terjadi pada saat "sesuatu" yang melekat pada dinding rahim ibu berubah menjadi darah beku yang bercampur yang menurut Bucaille (1979:304) berbentuk daging yang dikunyah. Tahapan ini terus berubah sampai muncul tulang-belulang yang melengkapi tahapan sebelumnya.

- Tahap tulang- belulang ( 'izâm )

Setelah berbentuk gumpalan daging, janin memasuki proses pembentukan tulang-belulang, kemudian tulang-belulang tersebut di kelilingi atau dibungkus dengan daging. Inilah yang dimaksud firman Allah dalam Q.S Al-Mu'minûn (23): 14:

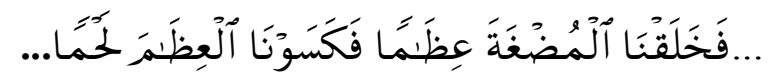

Terjemahnya:

...maka segumpal daging itu kami jadikan tulang belulang, lalu tulang belulang itu kami bungkus dengan daging...

- Tahap pemberian nyawa (nafkh al-rûh)

Setelah melalui proses perkembangan, mulai dari nut $\square$ fah, 'alaqah, mudghah, sampai tahap $i z \square \hat{a m}$, pertumbuhan kandungan sampai ke tahap penyempurnaan, yaitu dengan meniupkan ruh ke dalam jasad janinsehingga sempurnalah janin itu menjadi "bayi". Proses perkembangan penciptaan manusia yan demikian itu berjalan selama kurang lebih 9 bulan.

Yanggo (2002:101-102; Al-Najd, 1993:158-162) menjelaskan bahwa dari ayat tersebut, tahapan-tahapan kejadian manusia dapat dikemukakan sebagai berikut:

- dari tanah ( tîn );

- dari air hina (min mâ' mâhîn) yaitu dari air mani dan sperma;

- dari air yang terpancar ( $\min m \hat{a}^{\prime}$ dâfiq ) yang dalam buku-buku seks dikenal dengan istilah orgasme;

- dari setetes mani yang ditumpahkan kedalam rahim wanita (m̌in manî yumnâ) yang dalam embriologi dikenal bahan pancaran sperma ke dalam rahim melalui vagina masuk ke tuba fallopi guna bertemu dengan ovum;

- dari setetes mani yang terpancar (min nutah amsyâz) menurut embriologi adalah tahap awal pembuahan yang mana sperma sudah 
bertemu dengan ovum sehingga menjadi bersatu, atau dengan kata lain penyatuan gemit dari laki-laki dan perempuan;

- saripati air mani yang disimpan ditempat yang kokoh/rahim (nutfah fi qarâr makîn) nutfahmenurut Sayyid Qutub adalah setetes air mani yang keluar dari sulbi (tulang belakang) seorang laki-laki lalu bersarang di rahim wanita. Menurut ilmu embriologi, zygote berbentuk blastokel dan bersarang di selaput lendir rahim;

- segumpal darah ('alaqah) yang terjadi ketika benih laki-laki dan telur perempuan bersatu dan melekat pada dinding rahim. Sedangkan menurut embriolgi, blastokista manusia dalam minggu kedua terbenam dalam lendir rahim;

- segumpal daging ( lahm ) Menurut embriologi merupakan awal deferensiasi zygote setelah terbenam di lendir rahim;

- tulang belulang ('izâm), segumpal daging di atas membentuk tulang.

- daging (lahm ), tulang tadi dibungkus dengan daging;

- makhluk lain (khalq âkhâr) adalah manusia yang mempunyai ciriciri istimewa yang siap untuk meningkat.

\section{Pengertian Aborsi}

Kata aborsi dalam bahasa Inggris disebut abort atau abortion, yang berarti menggugurkan, berasal dari bahasa Latin, gugur kandungan atau keguguran (Anwar, t.th.:7). Dalam Ensiklopedi Indonesia (1980:60), aborsi diartikan sebagai pengakhiran kehamilan sebelum masa gestasi 28 minggu atau sebelum janin mencapai berat 1.000 gram. Sardikin Ginaputra dari Fakultas Kedokteran Universitas Indonesia, memberikan pengertian aborsi sebagai pengakhiran masa kehamilan atau hasil konsepsi (pembuahan) sebelum janin dapat hidup

Dari beberapa .pengertian di atas, dapat dikatakan bahwa aborsi adalah suatu perbuatan mengakhiri masa kehamilan dengan cara mengeluarkan janin dari kandungan sebelum janin itu dapat hidup di luar kandungan secara alami. Hasan (1998:44) menjelaskan bahwa sampai saat ini janin yang terkecil yang dapat hidup di luar kandungan ialah bila telah mempunyai berat badan 297 gram waktu lahir. Akan tetapi, karena jarang ditemukan janin yang dilahirkan dengan berat badan di bawah 1.000 gram dapat hidup terus, aborsi ditentukan sebagai pengakhiran kehamilan sebelum janin mencapai berat 1.000 gram. 
Uraian di atas menunjukkan bahwa untuk terjadinya aborsi, paling tidak ada tiga unsur yang harus di penuhi, yaitu (1) adanya embrio (janin) sebagai hasil pembuahan antara sperma dan ovum dalam rahim; pengguguran itu adakalanya terjadi dengan sendirinya, tetapi lebih sering disebabkan oleh perbuatan manusia;(2) keguguran itu terjadi sebelum waktunya; dan (3) masa kelahiran alami tiba (Saefullah dalam Yanggo \& Anshary, 1996:115):

Dalam literatur fikih, para fuqahâ' menggunakan istilah isqât, ijhâd, ilqâa", dan inzâl untuk aborsi.. (Bahawâtî, t.th.:220). dalam literatur fikih, istilah-istilah tersebut selalu digunakan secara bergantian karena mengandung makna yang berdekatan. Namun demikian, dalam tulisan ini digunakan istilah isqât untuk pengertian aborsi.

\section{Cara Pelaksanaan Aborsi}

Dalam melakukan aborsi, banyak cara yang biasa digunakan oleh masyarakat, antara lain dengan menggunakan tenaga medis di rumah sakit atau klinik-klinik kesehatan. Cara seperti ini pada umumnya dilakukan oleh para dokter yang hidup di negara yang melegalkan aborsi. Ada pula yang menggunakan jasa para dukun bayi yang kebanyakan berasal dari pedesaan dan menggunakan obat-obatan tradisional, seperti jamu dan lain-lain. Aborsi yang dilakuklan secara medis pada umumnya menggunakan metode sebagai berikut:

- Currattage dan Dilatage (C \& D);

- Dengan alat khusus, mulut rahim dilebarkan, kemudian janin dikiret dengan alat seperti sendok kecil;

- Aspirasi, yaitu penyedotan isi rahim dengan pompa kecil;

- Hysterotomi (melalui operasi) (Hasan, 1998:46).

Berbeda dengan cara yang biasa digunakan oleh dukun-dukun di pedesaan yang samasekali tidak memperhitungkan kesehatan, keselamatan, dan kehormatan perempuan yang sedang mengandung, seperti memijat perut atau pinggulnya secara paksa untuk mengeluarkan janin sehingga terjadi pendarahan yang mengakibatkan kematian. Bahkan seringkali ada wanita depresi dan frustasi yang menggugurkan sendiri kandungannya tanpa memperhitungkan resikonya. 


\section{Macam-macam Aborsi}

Keguguran bisa terjadi dengan sendirinya (secara alami) dan juga bisa pula terjadi karena campur tangan manusia. Bentuk yang kedua inilah (intervensi manusia) yang sering terjadi di tengah masyarakat. Secara umum, aborsi dapat dibagi ke dalam dua macam, yaitu pengguguran spontan (spontaneous abortion) dan pengguguran buatan atau disengaja (provocatus abortion).

\section{Aborsi Spontan}

Aborsi spontan ialah aborsi tidak sengaja (keguguran) dan terjadi tanpa tindakan apa pun. Aborsi seperti ini lebih sering terjadi karena fator di luar kemampuan manusia, seperti pendarahan (blooding) dan kecelakaan. Ini biasanya terjadi pada tiga bulan pertama dari masa kehamilan dan tidak ada satu cara pun untuk mencegah dan menghindari penyebab umum keguguran ini, bahkan dokter juga tidak dapat menentukan dengan cepat apa penyebabnya. Saefullah dalam (Al-Tariqî, t.th.:116) menyebut bentuk aborsi seperti ini dengan alIsqât al-'Afw. Oleh karena itu, dalam tulisan ini, jenis aborsi tersebut dibahas secara terbatas, karena tidak berimplikasi hukum diyat.

\section{Aborsi Buatan}

Aborsi buatan adalah pengguguran yang terjadi sebagai akibat dari suatu tindakan. Di sini, campur tangan manusia sangat jelas. Pengguguran kandungan dalam bentuk kedua ini dapat dibedakan ke dalam dua jenis, yaitu aborsi artificialis therapicus dan aborsi provocatus criminalis. Jenis aborsi yang disebutkan pertama dilakukan oleh dokter atas dasar indikasi medis. Hal ini dilakukan untuk menyelamatkan jiwa ibu yang terancam kehidupannya bila kelangsungan kehamilan dipertahankan. Misalnya, ibu tersebut menderita penyakit jantung, ginjal, dan penyakit jiwa, sedangkan yang disebutkan kedua, yaitu aborsi yang dilakukan bukan karena alasan medis. Biasanya aborsi jenis ini dilakukan karena adanya kehamilan yang tidak dikehendaki, baik karena problem ekonomi maupun karena hubungan seks di luar nikah.

Dalam urain berikut dapat dilihat bagaimana prosedur aborsi yang dilakukan secara sengaja berdasarkan pertimbangan medis. 


\section{Prosedur Pengguguran Kandungan Disengaja}

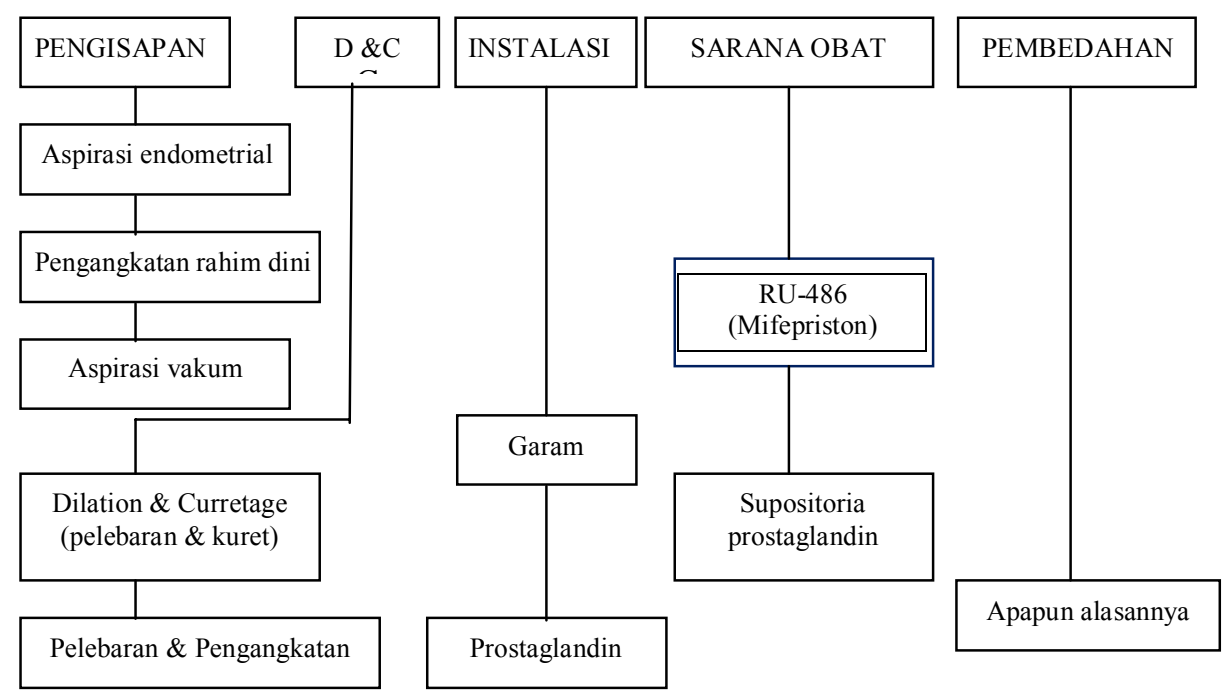

(Anes, 1991:48)

Skema di atas menjelaskan bahwa aborsi harus tetap dilakukan berdasarkan mekanisme medis untuk menjaga kehormatan dan keselamatan calon ibu. Hal ini menjadi pelajaran agar para pelaku aborsi yang dengan alasan medis membenarkan aborsi, harus tetap melakukannya berdasarkan pertimbangan medical science, bukan di tempat-tempat praktek aborsi yang ilegal.

Di atas telah dijelaskan bahwa pengguguran kandungan adakalanya dilakukan dengan bantuan ahli medis, dukun, atau dilakukan sendiri. Pengguguran yang dilakukakan oleh yang bukan ahlinya dan oleh yang tidak memenuhi persyaratan medis, lebih banyak menimbulkan akibat negatif, seperti komplikasi dan kematian. Saifullah, mengutip hasil penelitian di Amerika Latin yang dirangkum oleh Erik Eckholm (Saefullah dalam Yanggo \& Anshary, 1996:118) sebagai berikut:

- Statistik di rumah sakit El-Salvador menunjukkan bahwa 24\% dari angka kematian di rumah sakit tersebut adalah akibat pengguguran tidak sah;

- Selama tahun 1980-an, separuh dari kematian yang ada hubungannya dengan kelahiran di Santiago (Chili) adalah akibat pengguguran tidak sah; 
- Pada tahun 1964, sebuah penelitian di Cali (Kolombia) menemukan bahwa komplikasi akibat pengguguran adalah faktor utama yang menyebabkan kematian di kalangan wanita yang berumur 15-35 tahun;

- Di California tahun 1960-an, sebelum undang-undang pengguguran disahkan, komplikasi yang timbul dari pengguguran tidak sah menyebabkan satu dari lima kematian yang berhubungan dengan kelahiran, yang pada umumnya terjadi pada wanita berpenghasilan rendah.

Beberapa kasus di atas menunjukkan bahwa aborsi yang dilakukan para ahli medis bukan tanpa resiko buruk, justru banyak yang mengakibatkan komplikasi. Oleh karena itu, bagi yang akan melakukan aborsi harus mempertimbangkan resiko kesehatan dan keselamatan jiwanya.

PERSPEKTIF HUKUM ISLAM: SABAB AL-IKHTILÂF $A L$ $F U Q A H \hat{A}^{\prime}$

\section{Mazhab Hanafi}

Sebagian besar fuqahâ' Hanafiyah berpendapat bahwa aborsi dibolehkan sebelum janin terbentuk, yaitu sebelum peniuan ruh, tetapi harus disertai dengan syarat-syarat yang rasional, meskipun masalah kapan janin terbentuk masih diperselisihkan (ikhtilâf). Âlî al-Qâmî, salah seorang imam mazhab Hanafiyah memakruhkan aborsi. Pandangan tersebut sebagaimana ditulis oleh Al-Asrusyâni, salah seorang pengikut Hanafi, dalam kitab Jâmi' Ahkâm al-Shighâr bahwa para syaikh dari mazhab Hanafi umumnya mengatakan tidak makruh, sebagaimana disebutkan oleh penulis kitab Al-Mukhît. Imâm 'Âlî alQâmi memakruhkannya, demikian juga fatwa Abû Bakr Muhammad bin al-Fadl" (Al-Asrushâni, t.th.).

Menurut Al-Qâmî (dalam Al-Asrusyânî, t.th.), pengertian makruh dalam aborsi lebih condong kepada makna dilarang (haram) dikerjakan sehingga bilamana aborsi dilakukan, pelakunya dianggap berdosa dan patut diberi hukuman yang setimpal. Akan tetapi, pendapat tersebut ditolak oleh Al-Haskafi, salah seorang pengikut Hanafi yang lain, ketika ditanya, ia mengatakan, "Ya, sepanjang belum terjadi penciptaan dan penciptaan itu hanya terjadi sesudah 120 hari kehamilan."

Ulama yang membolehkan aborsi umumnya sependapat bahwa aborsi boleh dilakukan bilamana belum terjadi "penyawaan" karena 
dianggap belum ada kehidupan sehingga bilamana kandungan digugurkan, tidak termasuk perbuatan pidana (jinayat). Pendapat yang membolehkan aborsi sebelum janin berusia 120 hari adalah Ibn Âbidîn, salah satu pengikut Hanafi, yang menyatakan bahwa fuqaha mazhab ini membolehkan aborsi selama janin masih dalam bentuk segumpal daging, atau segumpal darah, dan belum terbentuk anggota badanya. Terbentuknya janin secara sempurna adalah setelah janin berusia 120 hari. Aborsi masih dibolehkan sebelum kandungan sampai usia itu karena janin belum menjadi manusia" (Ibn 'Âbidîn: 2001:202). Pendapat tersebut dibantah oleh ulama lain dengan alasan bahwa penciptaan terjadi sesudah janin berusia 80 hari. Jika janin telah melalui dua kali empat puluh hari ( 80 hari), Allah telah mengutus malaikat kepadanya lalu membentuk dan menciptakan pendengaran, penglihatan, dan kulitnya.

Al-Bûtî (1979:179) mengemukakan bahwa aborsi dibolehkan sebelum kehamilan memasuki bulan keempat hanya dalam tiga kasus, yaitu pertama, apabila dokter khawatir bahwa kehidupan ibu terancam akibat kehamilan; kedua, jika kehamilan dikhawatirkan akan menimbulkan penyakit pada tubuh ibu; dan ketiga, apabila kehamilan yang baru menyebabkan terhentinya proses penyusuan bayi yang sudah ada padahal kehidupannya sangat bergantung pada susu ibunya.

Dasar dibolehkannya aborsi pada tahap sebelum terjadinya "pemberian nyawa" ialah karena setiap sesuatu yang belum bernyawa tidak akan dibangkitkan di hari kiamat. Begitu pula dengan janin yang belum diberi nyawa. Sumber lain yang paling banyak dikutip dari mazhab ini adalah aborsi dibolehkan bilamana ibu yang hamil sedang dalam keadaan menyusui anaknya yang lain sehingga air susunya terhenti, sementara bapaknya tidak mempunyai biaya untuk menyediakan susu pengganti. Bila keadaan ini terjadi, aborsi dibenarkan karena untuk memelihara kehidupan anak yang sedang menyusu. Aborsi juga dibolehkan jika akan terjadi sesuatu yang buruk pada ibu pada saat melahirkan.

Adapun dari segi konsekuensi hukum bagi pelaku aborsi, ada beberapa pendapat. Menurut Al-Tahtawi dalam (Al-Hanâfî, t.th.:285), apabila janin yang digugurkan itu dalam fase 'alaqah atau mudghah, pelakunya tidak wajib dikenai denda janin, tetapi cukup dihukum dengan kadar hukuman yang ditentukan oleh hakim (ta'zîr) karena ia dianggap telah merusak sesuatu yang sangat berharga. Menurut AlAsrusyânî (t.th.:159), pelaku aborsi wajib membayar uang kompensasi (ghurrah) bilamana kehamilan yang digugurkan telah berusia empat 
bulan, tetapi jika kurang dari usia tersebut, uang kompensasi tidak wajib. Menurut Abû Bakr (dalam Al-Asrusyânî, t.th.:164), meskipun janin yang digugurkan baru dalam bentuk segumpal daging (mudghah) dan pelakunya tidak perlu didenda, ia harus bertobat kepada Allah atas kecerobohannya sehingga merusak martabat cikalbakal manusia.

Al-Musili dalam (Al-Bûtî, 1979) berpendapat bahwa aborsi dibolehkan sebelum janin melewati usia 42 hari. Demikian beberapa pandangan mazhab Hanafiyah tentang aborsi.

\section{Mazhab Hanbali}

Menurut jumhur ulama Hanabilah, janin boleh digugurkan selama selisih masih dalam fase segumpal daging karena belum berbentuk manusia, sebagaimana ditegaskan oleh Ibn Qudâmah dalam kitab Al-Mughnî bahwa:

\footnotetext{
Pengguguran terhadap janin yang masih berbentuk mudghah dikenai denda (ghurrah), bila menurut tim spesialis ahli kandungan janin sudah terlihat bentuknya. Namun, apabila baru memasuki tahap pembentukan, dalam hal ini ada dua pedapat; pertama yang paling sahih adalah pembebasan hukuman ghurrah, karena janin belum terbentuk misalnya baru berupa 'alaqah, maka pelakunya tidak dikenai hukuman, dan pendapat kedua; ghurrah tetap wajib karena janin yang digugurkan sudah memasuki tahap penciptaan anak manusia (Qudâmah, t.th.:62).
}

Ibn Najjâr dalam (Al-Bûtî, 1979:79) menjelaskan bahwa lakilaki dibolehkan meminum obat untuk pencegahan terjadinya coitus, sedangkan perempuan dibolehkan meminum peluntur untuk menggugurkan nutfah. Namun, pendapat yang paling kuat dari mazhab ini seperti dikemukan oleh Ibn Jauzî bahwa aborsi hukumnya haram mutlak, baik sebelum atau setelah persenyawaan pada usia 40 hari

Dari penjelasan di atas, dapat dikemukakan bahwa para fuqaha Hanabilah lebih cenderung mengatakan bahwa aborsi dibolehkan sebelum terjadinya penciptaan, yaitu sebelum janin berusia 40 hari.

\section{Mazhab Syafi'i}

Ulama Syafi'iyah berselisih pendapat mengenai aborsi sebelum janin berusia 120 hari. Ada yang mengharamkannya, seperti Al-Imâd, dan adapula yang membolehkannya selama masih berupa seperma 
atau sel telur (nutfah) dan segumpal darah ('alaqah) atau berusia 80 hari. Akan tetapi, sebagian besar dari fuqahâ' Syafi'iyah menyepakati bahwa aborsi haram sebelum usia kehamilan 40-42 hari. Dalam Ihyâ ' Ulûm al-Dîn Al-Ghazâlî (1980:158) mengatakan bahwa senggama terputus (al-azl) tidak dapat disamakan dengan aborsi (ijhad) karena ijhad merusak konsepsi atau pembuahan (maujud al-hâsil), percampuran antara nutfah dengan ovum, dan merusak konsepsi merupakan perbuatan jinâyah yang ada sanksi hukumnya. Mengapa? Karena kehidupan itu berkembang dan dimulai secara bertahap. Awalnya nutfahdipancarkan kedalam rahim, lalu bercampur dengan sel telur perempuan, kemudian setelah itu ia siap menerima kehidupan. Merusak hasil pembuahan tersebut adalah jinayah. Jinayah akan semakin besar sesuai dengan usia janin yang dirusak. Jinayah akan sampai pada puncaknya jika janin terpisah dari tubuh ibunya dalam keadaan hidup kemudian mati

Al-Ghazâlî (1980:158) mengatakan bahwa menurut pendapat yang paling benar, aborsi dalam bentuk segumpal darah ('alaqah) dan segumpal daging (mudghah) atau sebelum penciptaan, tidak apa-apa dilakukan. Sementara sebagian ulama Syafi'iyah yang lain mengatakan bahwa aborsi dibolehkan sepanjang janin belum terbentuk sempurna, yaitu belum tampak bagian-bagian tubuhnya, seperti tangan, kaki, kepala, rambut, dan bagian-bagian tubuhnya yang lain. Al-Ramlî (t.th.:416), ulama Syafi'iyah, mengharamkan aborsi secara mutlak setelah peniupan ruh dan membolehkannya jika peniupan ruh belum dilakukan.

Sejak peniupan ruh hingga bayi dilahirkan, melakukan aborsi haram hukumnya. Adapun sebelum peniupan ruh tidak diharamkan, sedangkan saat yang mendekati waktu peniupan ruh, diperselisihkan apakah boleh atau haram karena itu adalah waktu yang mendekati waktu keharamanya. Sebagian ulama menentukan batas "penyawaan" adalah 42 hari, yang berarti aborsi boleh dilakukan sebelum kandungan berusia 42 hari dan haram dilakukan bila lewat usia 42 hari. Dasar yang digunakan adalah hadis nabi saw.

Aku mendengar Rasulullah saw. bersabda bahwa apabila nutfah telah melewati 42 hari Allah mengutus malaikat untuk membentuk rupanya, menjadikan pendengaranya, penglihatanya, kulitnya, dagingnya, dan tulangnya, kemudian malaikat bertanya:" Wahai Tuhanku, apakah dijadikan laki-laki 
atau perempuan? Lalu Allah menentukan apa yang dikehendaki, lalu malaikat itu pun menulisnya" (H.R. Muslim).

Begitu pula Imâm al-Nawâwî mengharamkan aborsi pada tahap mudghah yang telah berbentuk manusia karena sudah memiliki mata, telinga, tangan dan lain-laina. Menurut al-Nawâwî, janin pada fase tersebut bila dirusak ada dendanya (diyat). (Al-Nawâwî ) Sebab merusak anak dalam perut (al-walad fî al-batn) merupakan tindakan pidana, tidak boleh dirampas hak kehidupannya.

Para ulama Syafi'iyah berbeda pendapat tentang hukum aborsi sebelum peniupan ruh (qabl al-nafkh al-rûh), tetapi sepakat mengharamkan aborsi setelah peniupan ruh (ba'da nafkh al-rûh), sebagaimana dikemukakan oleh (1991) bahwa para ulama sepakat mengharamkan pengguguran kandungan yang dilakukan bagi kaum muslimin, melakukan hal itu merupakan pelanggaran pidana (janâyah) atas makhluk yang hidup.

Akibat hukum bagi pelaku pengguguran kandungan setelah "penyawaan", menurut pendapat mayoritas ulama Syafi'iyah, ialah wajib membayar kompensasi (ghurrah). Al-Juzaiyrî mengatakan bahwa janin yang digugurkan akibat tindak pidana (jinâyah) wajib diganti dengan uang kompensasi, baik terpisah dari tubuh ibunya ketika ibunya masih hidup maupun setelah ibunya meninggal. Demikian pula, bila janin keluar sebagian, tidak terpisah seluruhnya, seperti keluar kepalanya dalam keadaan sudah meninggal (Al-Juzaiyrî, t.th.:102).

Imâm al-Zarkâsî dan Imâm al-Ramlî mengemukakan bahwa aborsi dibolehkan ketika usia janin dalam proses nutfahatau 'alaqah. Pendapat ini disandarkan pada pernyataan Abû Bakr bin Abû Sa'îd alFurâtî ketika ditanya oleh Al-Karabîsî tentang seorang laki-laki yang memberi minuman peluntur kepada jariyah-nya. Al-Furâtî menjawab hal tersebut dibolehkan selagi masih berupa nutfahatau 'alaqah. Selanjutnya Al-Ramlî, menjelaskan bahwa sebelum peniupan ruh, aborsi tidak disebut dengan khilâf al-aulâ, melainkan mengandung kemungkinan makruh. Ibn Hajar membolehkan aborsi sebelum usia kandungan 42 hari, tetapi bila lebih dari itu dilarang.

\section{Mazhab Maliki}

Ulama Malikiyah berpendapat bahwa kehidupan sudah dimulai sebelum konsepsi. Oleh karena itu, menurut mereka, aborsi tidak dibolehkan bahkan sebelum janin berusia 40 hari, kecuali Al-Lâkim, 
yang membolehkan aborsi sebelum janin berusia 40 hari. Tidak dibolehkan melakukan aborsi bila air mani telah tersimpan dalam rahim, meskipun belum berumur 40 hari. Begitu juga menurut AlLaisî, jika rahim telah menangkap air mani, maka tidak boleh suami istri ataupun salah satu dari mereka menggugurkan janinnya, baik sebelum penciptaan maupun sebelum peniupan ruh (Al-Bûtî, 1979:80).

Al-Lâkim membolehkan pengguguran kandungan sebelum berusia 40 hari dan tidak harus menggantinya dengan denda apa pun. Bahkan ulama Malikiyah lain memberi keringanan (rukhshah) pada kehamilan akibat perbuatan zina, yaitu janin boleh digugurkan sebelum fase peniupan ruh jika takut akan dibunuh jika diketahui kehamilannya. Akan tetapi, menurut mayoritas ulama Malikiyah, aborsi boleh dilakukan hanya untuk menyelamatkan nyawa ibu, selain itu mutlak dilarang. Pandangan demikian dapat dilihat dalam Komite Fatwa Al-Azhar yang ditulis oleh Gamal Surur, yang mengkategorikan aborsi setelah "penyawaan" sebagai kejahatan yang terkutuk, tidak peduli apakah kehamilan tersebut hasil dari pernikahan yang sah atau karena hubungan gelap (zina), kecuali jika aborsi tersebut bertujuan untuk menyelamatkan nyawa ibunya (Ibn Rushd, t.th.:416).

Pelaku aborsi wajib dikenai hukuman sesuai dengan usia kandungan yang digugurkannya. Semakin tua usia kandungan yang digugurkan semakin besar pula tebusan yang wajib dibayar kepada ahli warisnya. Mayoritas ulama Malikiyah sepakat untuk memberi hukuman (ta'zîr) bagi pelaku aborsi bilamana belum terjadi "penyawaan" pada kandungan (qabl nafkh al-rûh). Namun, AlQurt $\square$ ubî mewajibkan membayar kompensasi, sebagaimana pendapat Imam Malik dalam kitab Bidâyat al-Mujtahid, yaitu apa saja yang terlepas dari rahim ibu hamil, walaupun dalam bentuk mudghah ataupun 'alaqah, apabila ia diyakini sebagai anak dalam kandungan, maka pihak yang bertanggung jawab wajib menebusnya dengan ghurrah" (Ibn Hazm, t.th.:35-40).

Ulama yang melarang perbuatan aborsi mengatakan bahwa kehidupan berkembang dan dimulai sejak konsepsi. Ulama yang melarang aborsi sejak konsepsi sebagian besar dari mazhab Maliki, sedangkan ulama dari mazhab lain yang berpendapat serupa, antara lain ialah Imâm al-Ghazâlî dari mazhab Syafi'i, Ibn Jauzî dari mazhab Hanbali, dan Ibn Hazm dari mazhab Dhahiri (Al-Tarîqî, 1983:201). Adapun ulama yang membolehkan aborsi sebagian besar dari mazhab 
Hanafi dan Syafi'i dengan alasan (1) belum terjadi "penyawaan" sehingga dianggap belum ada kehidupan; (2) selama janin masih dalam bentuk segumpal daging, atau segumpal darah dan belum terbentuk anggota badannya; (3) janin boleh digugurkan selama masih dalam fase segumpal daging karena belum berbentuk anak manusia;(4) aborsi boleh dilakukan hanya untuk menyelamatkan nyawa ibu; (5) keringnya air susu ibu yang disebabkanoleh kehamilan; dan (6) ketidakmampuan ibu menanggung beban kehamilan karena tubuhnya yang kurus dan rapuh.

\section{MUNÂQASYAT AL-'ADILLAH}

Pertama, golongan yang mengharamkan pengguguran kandungan pada setiap tahapan pertumbuhan janin sebelum diberi nyawa (nutfah, 'alaqah, dan mudghah), seperti disebutkan oleh sebagian ulama Hanafiyah, Malikiyah, Imâm al-Ghazâlî (Syafi'iyah). Mereka mengemukakan beberapa hadis sebagai alasan untuk menguatkan pendapat, antara lain hadis Rasulullah saw.:

Sesungguhnya Allah swt. bila ingin menciptakan manusia (al'Abd), Ia mempertemukan antara laki-laki dan perempuan yang kemudian akan memancar sperma ke setiap pembuluh dan anggotanya. Jika sudah sampai pada hari ketujuh, Allah swt menghimpunnya lalu mendatangkan pada setiap pembuluhnya, kecuali penciptaan Adam (HR. Al-Thabrani).

Menurut hadis di atas, tahap penciptaan dan pembentukan manusia dimulai dari sperma (nutfah). Jika pembentukan sudah dimulai pada tahap ini, menggugurkan kandungan merupakan suatu hal yang tidak dibolehkan.

Kedua, golongan yang membolehkan pengguguran pada salah satu tahap dan melarang pada tahap-tahap yang lain; atau melarang aborsi pada salah satu tahap dan membolehkannya pada tahap-tahap yang lain, dikemukakan berikut ini:

- Makruh pada tahap nutfahdan haram pada tahap 'alaqah dan mudghah. Ini adalah pendapat Malikiyah.

- Syafi'iyyah disebut sebagai makruh tanzih, dengan syarat pengguguran itu atas izin suami.

- Boleh pada tahap nutfah, dan haram pada tahap 'alaqah serta mudghah.

- Boleh pada tahap nutfahdan 'alaqah, tetapi haram pada tahap mudghah. 
Jika diperhatikan beberapa pendapat di atas, hampir tidak ditemukan dalil atau argumentasi yang menjadi sandaran, kecuali pendapat yang mengatakan boleh pada tahap nutfahtetapi haram pada tahap 'alaqah dan mudghah. Berdasarkan sebuah hadis yang terjemahannya sebagi berikut:

Apabila nutfah telah melalui masa empat puluh dua malam, Allah akan mengutus kepadanya malaikat untuk memberi bentuk, menciptakan pendengaran, penglihatan, kulit, daging dan tulang- belulang...(HR. Muslim).

Hadis di atas menunjukkan bahwa pembentukan wajah pada janin, penciptaan pendengaran, penglihatan, kulit, daging, dan tulangbelulang terjadi pada permulaan empat puluh hari yang kedua. Dengan demikian, jelaslah bahwa pada tahapan ini janin sudah berbentuk daging dan tulang. Sedangkan sebelumnya, janin belum berbentuk apa-apa dan masih berupa cairan sperma sehingga masih memungkinkan digugurkan.

Ketiga, golongan yang membolehkan aborsi pada setiap tahapan dari tahap sebelum bernyawa (nutfah, 'alaqah, mudghah). Ini pendapat yang kuat dikalangan ulama Hanafiyah. Alasan mereka adalah (1) setiap yang belum diberi nyawa tidak akan dibangkitkan Allah pada hari kiamat. Setiap yang tidak dibangkitkan, keberadaannya tidak diperhitungkan. Dengan demikian, tidak ada larangan untuk menggugurkan kandungan; dan (2) janin sebelum diberi nyawa tidak tergolong sebagai manusia. Oleh karena itu, tidak ada larangan untuk menggugurkannya

Pendapat ketiga ini dapat disanggah dengan argumentasi bahwa apabila tetap dibiarkan dalam rahim, kandungana akan tumbuh secara alami sampai diberi nyawa. Apabila telah bernyawa, berarti kandungan telah menjadi manusia, dan dalam kondisi ini pasti ada kebangkitan. Menganiaya dan merusak kandungan setelah diberi nyawa berarti sama halnya dengan menghentikan pertumbuhannya. Apabila ini dilakukan tanpa alasan hukum, yang melakukannya akan diberi kaffarah dan berdosa.

Jumhur ulama mazhab Hanafi, Hanbali, Maliki, dan Syafi'i, termasuk yang melarang aborsi pada setiap tahap pertumbuhan janin dalam aborsi Provocatus Criminalis atau al-Isqât al-Ikhtiyârî) dan ulama-ulama kontemporer, seperti Mahmûd Shaltût dan Yûsuf alQardâwî, lebih mengutamakan aspek kemaslahatan dan keselamatan ibu yang mengandung, masih mentolerir aborsi dalam kedaan 
darurat. Tujuannya ialah untuk menyelamatkan nyawa ibu yang sedang mengandung.

\section{PENUTUP}

Berdasarkan uraian di atas dapat disimpulkan bahwa sejak sel sperma bertemu dengan ovum, saat itu pula telah terjadi pembuahan sehingga pada kondisi ini melakukan aborsi dipandang sebagai kejahatan yang hukumnya haram. Walaupun janin belum bernyawa, tetapi karena sudah ada kehidupan pada janin yang sedang mengalami pertumbuhan dan perkembangan serta persiapan untuk menjadi makhluk baru (manusia) yang bernyawa, maka ia harus dihormati dan dilindungi keberadaannya sebagai makhluk Tuhan. Syariat Islam menegaskan bahwa semakin besar kandungan yang digugurkan, semakin besar pula jinayahnya (tindak pidananya), yang berarti semakin besar pula dosa bagi yang melakukannya, meskipun janin itu merupakan akibat dari hubungan gelap atau selingkuh (di luar perkawinan yang sah), seperti yang biasa terjadi di masyarakat.

\section{DAFTAR PUSTAKA}

Abî Muhammad 'Abd Allâh Ahmad ibn Muhammad ibn Qudâmah. t.th. AlMughnî. Juz XII. Riyâd: Maktabat al-Riyâd al-Hadîthah.

$\mathrm{Ah} \square \operatorname{mad}$ bin Rushd. t.th. Bidâyat al-Mujtahid. Beirut: Dâr al-Ma'rifah.

Anees, Munawar Ahmad. 1991. Islam dan Masa Depan Biologis Umat Manusia, Etika, Gender, dan Teknologi. Bandung: Mizan.

Anwar, Desy. t.th Kamus Lengkap Milliard Inggris-Indonesia, Indonesia Inggris. Surabaya: Amelia.

al-Bahawâtî. t.th. Kashf al-Qinâ.' Juz I. Riyâd: Maktabat al-Nasr alHadithah.

Bucaille, Maurice. 1979. Bible, Qur'an dan Sains Modern. Cet. ke-2. Jakarta: Bulan Bintang.

al-Bûtî $\square$, Muhammad Sa'îd Ramadân.1979. Tahdîd al-Nasl. Damaskus: Maktabat al-Farabî.

Ensiklopedi Indonesia. 1980. Jakarta: PT. Ichtiar Baru Van Hoeve.

al-Ghazâlî. 1939. Ihyâ' 'Ulûm al-Dîn. Mesir: Mustafâ al-Bâb al-Halabî.

al-Hânafî, Ahmad al-Tahtâwî. t.th. Hashiyah al-Tahtâwi 'alâ al-Mukhtâr. Juz IV. Beirut: Dâr al-Ma'rifah.

al-Hanafî, Muhammad ibn Mahmûd ibn al-Husayn ibn Ahmad al-Asrusyânî. t.th. Jâmi' al-Ahkâm al-Shighâr. Dâr al-Fadîlah.

Hasan, M. Ali. 1998. Masail Fiqhiyah al-Haditsah pada Masalah-masalah Kontemporer Hukum Islam. Cet. ke-3. Jakarta: PT.Raja Grafindo. 
Husain Muhammad. 2001. Aborsi dalam Perspektif Fikih Kontemporer. Makalah disajikan dalam Seminar dan Lokakarya Aborsi, Pengurus Pusat Fatayat NU, Jakarta, 27 April.

Ibn 'Âbidîn. 1966. Hashiyyat ibn 'Âbidîn. Juz III. Mesir: Mustafâ al-Bâb alHalabî.

Ibn Hazm t.th. Al-Muhalla. Juz XI. Beirut: Dâr al-Afaq al-Jâdilah.

Ibn Qudâmah. t.th. Al-Mughnî. Juz VII. Riyad: Maktabah al-Riyâd alHadîthah.

al-Juzayrî, 'Abd al-Rahmân. t.th. Al-Fiqh 'alâ al-Madhâhib al-Arba'ah. Jilid 5. Beirut: Dâr al-Fikr.

al-Khâtib wa al-Nawâwî. t.th. Mughnî al-Mukhtâj. Jilid 4. Beirut: Dâr alShuruq.

al-Naysabûrî, Abî al-Husayn Muslim bin al-Hajjaj. 1992. Sahîh Muslim. Hadis ke-2645. Jilid 2. Beirut: Dâr al-Fikr.

al-Nawâwî. t.th. Raudat al-Tâlibîn. Juz VII. Beirut: Dâr al-Kutub al'Ilmiyah.

al-Qashbî, Mahmûd Zalat 1991. Al-Islâm wa al-Tuafûlah. Al-'Ulum alSukkaniyyah. Qâhirah: Jâmi'at al-Azhâr.

al-Qurtubî, t.th. Tafsîr al-Qurtûbî. Juz V. Kairo: Dâr al-Sya'ab.

al-Ramlî, Syamsuddin Muhammad bin Abî al-'Abbâs Ahmad ibn Hamzah ibn Sihâb al-Dîn. t.th. Nihâyah al-Mukhtâj ilâ Sharh al-Minhâj. Jilid 7. Beirut: Maktabat al-Islâmiyah.

Rita Serena Kalibonso. 2001. Aborsi Ditinjau dari Perspektif Hukum Fact Sheet Peraturan Aborsi di Dunia. Forum Kesehatan Perempuan. Lembar Informasi Edisi ke-1 /02/Maret/2001.

Saifullah. 1996. Abortus dan Permasalahannya (Suatu Kajian Hukum Islam. Dalam Huzaemah T.Yanggo dan H.A. Hafiz Anshary A.Z (Ed.) Problematika Hukum Islam Kontemporer II. Jakarta: LSIK.

Sayyid Qutub. t.th. Fî̀ Zilâl al-Qur'ân. Jilid 4. t.tp. t.p.

al-Tarîqî, 'Abd Allâh ibn 'Abd al-Muhsin. 1983. Tandhîm al-Nasl wa Mauqif al-Sarî' at al-Islâmiyyah minhu. Riyâd: t.p.

Tim Penyusun LBH APIK. t.th. Aborsi dan Hak Pelayanan Kesehatan. Jakarta: Lembar Informasi Seri 32.

Yanggo, Huzaemah T. 2002. Dialog Aborsi dalam Perspektif Agama Islam. Dalam Wan Nedra (Eds.). Aborsi dalam Perspektif Fiqh Kontemporer. Jakarta: Fakultas Kedokteran Universitas Indonesia.

Yasin, M. Nu'aim. 2001. Fikih Kedokteran. Jakarta: Pustaka Al- Kautsar.

Zuhdi, Masjfuk. 1989. Masail Fiqhiyah. Jakarta: CV. H. Mas Agung. 